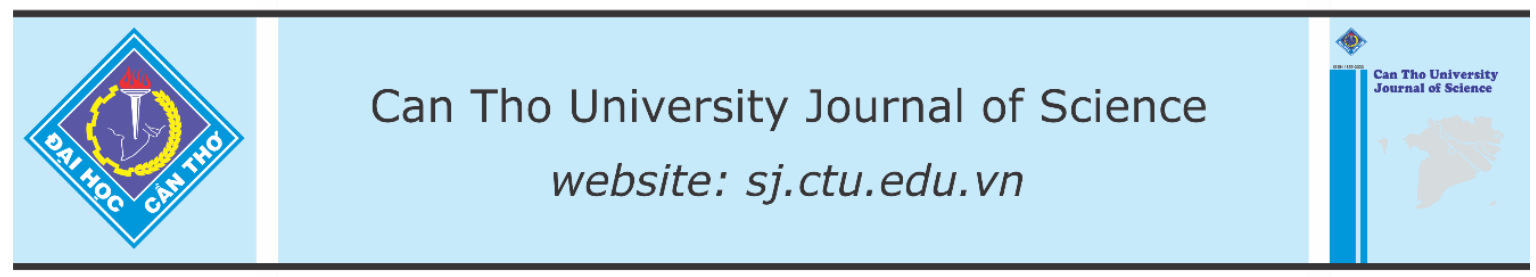

DOI: 10.22144/ctu.jen.2021.005

\title{
Isolation and screening of carotenoid-producing Bacillus spp. from seashore saline soil and seawater at Hon Son islet
}

\author{
Bang Hong Lam ${ }^{1,2}$, Huynh Nguyen Nhu Ngoc ${ }^{2}$, Nguyen Le Thanh Dat $^{2}$ and Nguyen Minh Chon ${ }^{2 *}$ \\ ${ }^{1}$ Faculty of Agriculture and Natural Resources, An Giang University - Vietnam National University Ho Chi \\ Minh City, Vietnam \\ ${ }^{2}$ Biotechnology Research and Development Institute, Can Tho University, Vietnam \\ *Correspondence: Nguyen Minh Chon (email: nmchon@ctu.edu.vn)
}

\section{Article info.}

Received 05 Sep 2020

Revised 28 Oct 2020

Accepted 31 Mar 2021

\section{Keywords}

Bacillus spp., carotenoid, $16 \mathrm{~S}$ rRNA, pigments

\begin{abstract}
Carotenoids are natural pigment compounds with a variety of colors. They are antioxidants and boost the immune system. It is interesting to examine strains of bacteria capable of producing carotenoids applied in the food industry, animal feed, and aquaculture. Rach Gia bay of Kien Giang province has a good ecosystem, and the carotenoid-producing microorganisms in these regions are very plentiful. However, there are fewer studies about them in this region. This study was conducted to isolate and select carotenoids-producing Bacillus from Hon Son islet of Rach Gia bay. Seashore saline soil and seawater samples were shocked at $65^{\circ} \mathrm{C}$ in 1 hour and plated on Difco sporulation medium. Colored colonies of bacteria were selected and incubated at $37^{\circ} \mathrm{C}$ on Difco sporulation medium. Pigments from these isolates were extracted in the mixture of methanol and chloroform (with the ratio 1:2 of $v / v$ ). The extracted solutions were scanned absorbance by spectrophotometer at the wavelength range from 400 to $600 \mathrm{~nm}$. Bacterial isolates were identified by $16 \mathrm{~S}$ rRNA sequencing. Twenty carotenoid-producing bacterial species were isolated, including five colony colors such as pale yellow, yellow, yellow-orange, pale pink, and pink. They were Gram-positive, positive - catalase test, motile, and endospore-forming. The results of extracted solutions from 20 bacterial species indicate that all the extracts have absorbance from 400-600 nm, this is the popular absorbance of carotenoids. Two high-carotenoid-producing species (HS3-7 and HS8-3) were analyzed the 16S rRNA gene sequence. They were showed high similarity with Bacillus vietnamensis species Marseille-P799 and Bacillus infantis species NRRL B-14911, respectively.
\end{abstract}

\section{INTRODUCTION}

Carotenoids are one of the largest and most diverse groups of biologically active substances, which are responsible for the colors of yellow, orange, and red in many plants, microorganisms, and animals. These natural products can protect cells against harmful oxygen radicals or serve as a precursor of vitamin A, a membrane stabilizer (Asker et al., 2012). Therefore, these natural pigments have received considerable attention for product development applied in biotechnology, food industry, animal 
feed, aquaculture, and pharmaceutical industry (Fiedor \& Burda, 2014; Vílchez et al., 2011). However, commercial carotenoids are mainly produced by chemical synthesis methods. The microbiological pigments can replace the synthetic colors because they are completely natural, high productivity, and diversity of molecules (Indra Arulselvi et al., 2014).

The bacterial spores are well-documented about their survivability in harsh conditions such as high temperature, toxic chemical, or UV radiation $(\mathrm{Ni}-$ cholson et al., 2000; Riesenman \& Nicholson, 2000). Carotenoids are secreted to help the bacterial spores withstand UV damage. Bacillus subtilis spores have melamine in their coats to help them survive under solar radiation. Furthermore, a wide range of carotenoid pigments is also found in the membrane of Bacillus spp. that can scavenge reactive oxygen species (ROS) that originated from UV radiation (Khaneja et al., 2010). For examples, $B$. aquimaris and $B$. marisflavis produce yellow pigments (Yoon et al., 2003), B. indicus and B. clarkii with yellow and orange pigments (Duc et al., 2006; Nielsen et al., 1995), B. firmus with pink pigment (Khaneja et al., 2010) and B. megaterium with red pigment (Mitchell et al., 1986). Carotenoid production in spore-forming Bacillus species has attracted interest from both academia and industries because of their potential to act as a biological source for mass-production of these natural compounds with improved stability and solubility for the feed and food industry (Abdel-Fattah et al., 2012). In this present study, carotenoid-producing Bacillus spp. with high productivity were isolated, screened, and identified from seashore saline soil samples and seawater samples at Hon Son islet, Kien Hai district, Kien Giang province.

\section{MATERIALS AND METHODS}

\subsection{Materials}

\subsubsection{Sample collection}

Seven saline soil samples from the seashores and two seawater samples were collected from Hon Son islet, Kien Hai district, Kien Giang province at a depth of $2-5 \mathrm{~cm}$ from the soil and seawater surface, respectively. Soil $(500 \mathrm{~g})$ and seawater $(500 \mathrm{~mL})$ samples were kept in plastic bags and sterile bottles, respectively, and transferred to the laboratory for isolation.

\subsubsection{Chemicals}

Difco sporulation medium (DSM) and Luria-Bertani medium (LB) were purchased from Himedia, India. Methanol 99.5\%, phosphate-buffered saline (pH 7.4), and chloroform $99.5 \%$ were purchased from Merck, Germany. F-primer f27, R-primer r1492, DNA master mix, and PCR water were purchased from Phusa biochem LTD. Company.

\subsection{Methods}

\subsubsection{Isolation of carotenoids-producing Bacillus spp.}

The isolation was referred to the method described in the study of Duc et al. (2006). Each sample was diluted $(1: 10)$ by phosphate-buffered saline (PBS, $\mathrm{pH}$ 7.4) in the flask. For sample preparation, $1 \mathrm{~g}$ of seashore saline soil was diluted by phosphate-buffered saline (PBS, $\mathrm{pH} 7.4)$ with the ratio 1:10 (w/v), and the seawater sample $(1 \mathrm{~mL})$ was diluted in PBS buffer with the ratio $1: 10(\mathrm{v} / \mathrm{v})$. The mixture was heated at $65^{\circ} \mathrm{C}$ for 1 hour to remove all vegetative cells. Next, serial dilutions (from $10^{-1}$ to $10^{-7}$ ) were made by using PBS, and $100 \mu \mathrm{L}$ of each diluted concentration was plated on DSM Petri dishes. After three days of incubation at $37^{\circ} \mathrm{C}$, colored colonies (from red to yellow) were selected and then transferred to new DSM Petri dishes to isolate single bacterial species. Each isolate was incubated at $37^{\circ} \mathrm{C}$ and the morphology was described based on Holt et al. (1994).

For the taxonomy identification, all species were confirmed by morphology and a series of biochemically tests including gram staining, catalase synthesis, mobility, and spore formation ability (Amin et al., 2012). The gram staining test was based on the standard protocol by using the Nam Khoa gram staining kit (Nam Khoa company, Viet Nam). The detailed procedures of catalase synthesis, mobility, and spore formation ability were described below.

Catalase synthesis: one bacterial colony was picked and put on the clean surface of the microscope slide, and one drop of hydroxyl peroxide (3\%) was dropped on the slide and allowed to contact the bacterial colony. The presence of bubbles caused by the hydrogen peroxide degradation reaction indicated the presence of catalase in the sample (positive result) while the negative results were represented by the disappearance of bubbles (Abdulkadir \& Waliyu, 2012). 
Mobility: Luria-Bertani semi-agar $(0,5 \%)$ was used for this assay. Inoculation was performed by the stab method with a straight needle. The sample was incubated at $37^{\circ} \mathrm{C}$ for 24 hours. The positive result was confirmed by a diffusion zone of microorganisms spreading from the inoculation line (Tittsler \& Sandholzer, 1936).

Spore formation ability: the bacterial smear was prepared and fixed on the clean surface of the microscope slide. Malachite green $5 \%$ was added to the fixed bacteria smear and then heated for a few minutes, which can soften the hard outer of the spore for sticking dye to the spore. After that, the sample was washed with distilled water to remove excess dye. Then, safranin dye $0,5 \%$ was added to samples. The green color indicated spores, and the pink color indicated vegetative cells (Oktari et al., 2017).

\subsubsection{Screening of carotenoids-producing Bacillus spp.}

Carotenoids compounds were extracted based on the method of Indra Arulselvi et al. (2014). One colony of each strain was pre-cultured in $10 \mathrm{~mL}$ Luria-Bertani medium (LB), incubated at $37^{\circ} \mathrm{C}$ and shaken at $200 \mathrm{rpm}$ by a shaker in 24 hours. Next, two $\mathrm{mL}$ of pre-inoculum was transferred into a $250 \mathrm{~mL}$ flask containing $100 \mathrm{~mL}$ of $\mathrm{LB}$, incubated at $37^{\circ} \mathrm{C}$, and shaken at $200 \mathrm{rpm}$ in 48 hours. Cells were harvested by centrifugation at $5,000 \mathrm{rpm}$ for 30 minutes at $4^{\circ} \mathrm{C}$, and then the pellet was washed with distilled water. For carotenoid extraction, six mL of methanol: chloroform $(1: 2, \mathrm{v} / \mathrm{v})$ was mixed with 0,2 grams of fresh pellet, and the suspension was sonicated at $200 \mathrm{~W}$ at $4^{\circ} \mathrm{C}$ for 10 minutes, which was following by adding $6 \mathrm{~mL}$ of distilled water into the tube. The suspension was separated by centrifugation at $12,000 \mathrm{rpm}$ for 15 minutes at $4^{\circ} \mathrm{C}$. The lower phase having carotenoids was collected. Extracted liquid was monitored at 400 to $600 \mathrm{~nm}$ by UV/VIS spectrophotometer (GENESYSTM 10S UV-Vis Spectrophotometer - Thermo Fisher). The total carotenoid content was calculated by the method of LiaaenJensen and Jensen (1971) with the following formula:

$$
c=\frac{D \times v \times f \times 10}{2,500}
$$

Where, $\mathrm{c}$ is total carotenoid content (mg); $\mathrm{D}$ is the maximum absorbance; $\mathrm{v}$ is the volume $(\mathrm{mL})$; $\mathrm{f}$ is dilution coefficient, 10 is the conversion factor to $\mathrm{mg}$, and 2,500 is the specific extinction coefficient of carotenoid.

\subsubsection{Identification of carotenoid producing strains by $16 S$ rRNA analysis}

High carotenoid-producing species were identified by $16 \mathrm{~S}$ rRNA analysis. The primers used for $16 \mathrm{~S}$ rRNA PCR were F-primer f27 (5'-AGAGTTTGATCCTGGCTCAG-3') and R-primer r1492 (5'GGTTACCTTGTTACGACTT-3') (Nugraheni et al., 2010). The PCR reaction was initiated by the denaturation step at $94^{\circ} \mathrm{C}$ for 2 minutes, which followed by 45 cycles of denaturation $\left(94^{\circ} \mathrm{C}\right.$ for 1 minute), annealing $\left(55^{\circ} \mathrm{C}\right.$ for 1 minute), and extension $\left(72^{\circ} \mathrm{C}\right.$ for 2 minutes), and the final extension step was $72^{\circ} \mathrm{C}$ for 10 minutes (Nugraheni et al., 2010). The electrophoresis of PCR products was performed by $2 \%$ agarose. The amplified products were then sequenced and subjected to DNA data bank by NCBI web-based BLAST program, and the closest species was identified by the percentage of identity. The sequences were aligned, and the phylogenetic tree was constructed by the MEGA X program.

\subsection{Statistical analysis}

The results of carotenoid extraction were expressed by mean of three replications. All data were processed by SPSS 20.0 software to determine statistical significance. The level of significance was set at $\mathrm{p}<0.05$.

\section{RESULTS AND DISCUSSION}

\subsection{Isolation of Bacillus spp. producing carotenoids}

There were 20 bacterial species isolated from seven seashore saline soil samples and two seawater samples at Hon Son islet. Four bacterial species were isolated from seawater samples (HS1-1, HS1-3, HS1-4 and HS2-1), and 16 species were isolated from seashore saline soil samples (HS3-3, HS3-4, HS3-7, HS3-8, HS4-1, HS5-1, HS5-2, HS5-3, HS61, HS7-1, HS8-3, HS8-6, HS8-7, HS8-8, HS8-9 and HS9-1).

On DSM Petri dishes, colonies of 20 bacterial species showed different colors: pale yellow, yellow, yellow-orange, pale pink, and pink. Bacterial colonies were all flat, circular, and entire or irregular and undulated, diameter range from 2-5 mm. Eight bacterial species were having circular and entire colonies, and 12 bacterial species having irregular and undulate colonies (Figure $1 \&$ Table 1). 


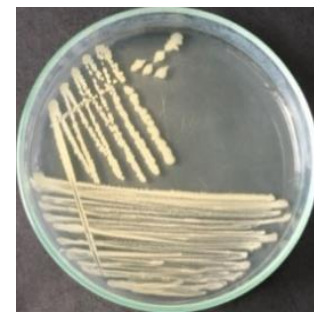

A- Pale yellow

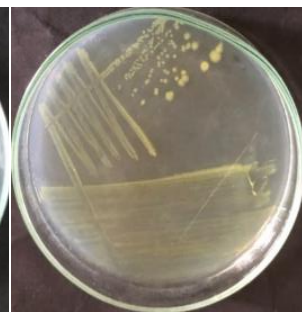

B- Yellow

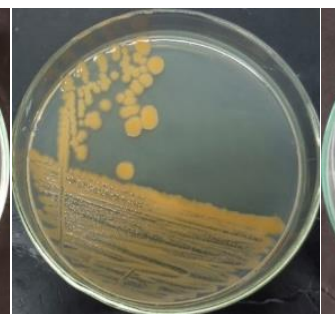

C- Yellow-Orange

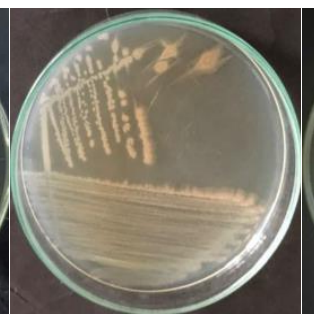

D- Pale pink

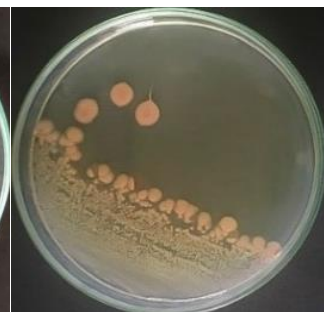

E- Pink

Figure 1. Colony color of HS1-1 (A), HS5-1 (B), HS3-7 (C), HS3-8 (D) and HS8-3 (E)

Table 1. The morphological characteristics of the colony of the isolated bacterial species

\begin{tabular}{clllllc}
\hline Order & $\begin{array}{l}\text { Bacterial } \\
\text { strains }\end{array}$ & $\begin{array}{l}\text { Colony } \\
\text { color }\end{array}$ & $\begin{array}{l}\text { Colony } \\
\text { shape }\end{array}$ & Colony edge & $\begin{array}{l}\text { Colony } \\
\text { surface }\end{array}$ & $\begin{array}{c}\text { Colony } \\
\text { diameter (mm) }\end{array}$ \\
\hline 1 & HS1-1 & Pale yellow & Irregular & Undulate & Flat & 3.0 \\
2 & HS1-3 & Pale yellow & Irregular & Undulate & Flat & 3.0 \\
3 & HS1-4 & Pale yellow & Circular & Entire & Flat & 2.0 \\
4 & HS2-1 & Pale yellow & Irregular & Undulate & Flat & 3.0 \\
5 & HS3-3 & Pale pink & Circular & Entire & Flat & 2.0 \\
6 & HS3-4 & Pale yellow & Irregular & Undulate & Flat & 3.0 \\
7 & HS3-7 & Yellow-orange & Irregular & Undulate & Flat & 4.0 \\
8 & HS3-8 & Pale pink & Circular & Entire & Flat & 3.0 \\
9 & HS4-1 & Pale yellow & Irregular & Undulate & Flat & 3.0 \\
10 & HS5-1 & Yellow & Circular & Entire & Flat & 2.0 \\
11 & HS5-2 & Pink & Circular & Entire & Flat & 4.5 \\
12 & HS5-3 & Yellow & Circular & Entire & Flat & 2.5 \\
13 & HS6-1 & Pale yellow & Irregular & Undulate & Flat & 3.0 \\
14 & HS7-1 & Yellow & Irregular & Undulate & Flat & 2.5 \\
15 & HS8-3 & Pink & Irregular & Undulate & Flat & 5.0 \\
16 & HS8-6 & Pale yellow & Irregular & Undulate & Flat & 2.0 \\
17 & HS8-7 & Pale yellow & Irregular & Undulate & Flat & 3.0 \\
18 & HS8-8 & Pale yellow & Irregular & Undulate & Flat & 5.0 \\
19 & HS8-9 & Yellow & Circular & Entire & Flat & 2.5 \\
20 & HS9-1 & Pale pink & Circular & Entire & Flat & 2.0 \\
\hline
\end{tabular}

Under the microscope at 1000X magnification, 20 isolates were rod-shaped cells with $(2-4 \mu \mathrm{m})$ in length and $1 \mu \mathrm{m}$ in width. All bacterial species were gram-positive, motile, able to form endospore, and synthesize catalase (Table 2). Based on the morphological and biochemical properties, 20 isolated species were identified as Bacillus spp. according to the key Bergey's manual of determinative bacteriology (Amin et al., 2012; Holt et al., 1994). 
Table 2. The morphological and biochemical characteristics of the isolated bacterial species

\begin{tabular}{cccccccc}
\hline Order & $\begin{array}{c}\text { Bacterial } \\
\text { strains }\end{array}$ & Shape & Size $(\mu \mathrm{m})$ & Gram & Catalase & Motile & Endospore \\
\hline 1 & HS1-1 & Rod & $2.5 \times 1$ & + & + & + & + \\
2 & HS1-3 & Rod & $2.0 \times 1$ & + & + & + & + \\
3 & HS1-4 & Rod & $4.0 \times 1$ & + & + & + & + \\
4 & HS2-1 & Rod & $4.0 \times 1$ & + & + & + & + \\
5 & HS3-3 & Rod & $3.0 \times 1$ & + & + & + & + \\
6 & HS3-4 & Rod & $2.5 \times 1$ & + & + & + & + \\
7 & HS3-7 & Rod & $3.0 \times 1$ & + & + & + & + \\
8 & HS3-8 & Rod & $3.0 \times 1$ & + & + & + & + \\
9 & HS4-1 & Rod & $2.0 \times 1$ & + & + & + & + \\
10 & HS5-1 & Rod & $2.0 \times 1$ & + & + & + & + \\
11 & HS5-2 & Rod & $3.5 \times 1$ & + & + & + & + \\
12 & HS5-3 & Rod & $2.0 \times 1$ & + & + & + & + \\
13 & HS6-1 & Rod & $4.0 \times 1$ & + & + & + & + \\
14 & HS7-1 & Rod & $2.5 \times 1$ & + & + & + & + \\
15 & HS8-3 & Rod & $3.5 \times 1$ & + & + & + & + \\
16 & HS8-6 & Rod & $3.5 \times 1$ & + & + & + & + \\
17 & HS8-7 & Rod & $2.5 \times 1$ & + & + & + & + \\
18 & HS8-8 & Rod & $2.0 \times 1$ & + & + & + & + \\
19 & HS8-9 & Rod & $2.0 \times 1$ & + & + & + & + \\
20 & HS9-1 & Rod & $2.5 \times 1$ & + & + & + & + \\
\hline
\end{tabular}

*(+): Gram-positive, Positive catalase test, Motile, and Form endospore.

\subsection{Selection of high carotenoid producing strains}

The extract colors of 20 Bacillus species were identified with the colony's color of each bacterial species. The carotenoid extracts of the bacterial species had 5 different colors, namely pale yellow, yellow, yellow-orange, light pink, and pink that have the highest absorbance at the wavelength of $400,448,460,495$, and $500 \mathrm{~nm}$, respectively (Table 3).

The yellow-orange pigment of the extract can be derived from $\phi, \phi$-Carotene, $\beta$-Carotene, and Zeaxanthin because these compounds have the highest absorbance at $460 \mathrm{~nm}$ (Table 3) (Britton et al., 2004; Butnariu, 2016). The total carotenoid extract of HS3-7 (yellow-orange) was estimated at 0.00287 $\mathrm{mg} / \mathrm{mL}$ and showed the highest carotenoid content among that of other species. On the other hand, the pale-yellow pigments had the maximum wavelength at $433 \mathrm{~nm}$, which could be $\alpha$-Carotene and Zeaxanthin, while the yellow pigments were $\gamma$-Carotene due to the maximum wavelength was $448 \mathrm{~nm}$ (Britton et al., 2004). The carotenoid extracted from HS5-2 and HS8-3 species had pink color, which reached a maximum wavelength at $500 \mathrm{~nm}$, while that of HS3-3, HS3-8, and HS9-1 species had pale pink color and had a maximum wavelength at 495 nm (Britton et al., 2004). The explanation for these results was that the pale pink pigment could be the mixture of Zeaxanthin and $\phi, \phi$-Carotene, while the pink pigment was the $\delta$-Carotene (Britton et al., 2004). The total carotenoid content of HS8-3 reached the second-highest one with 0.00250 $\mathrm{mg} / \mathrm{mL}$ to compare with that of other species, but this extract had pink color, so it might $\delta$-Carotene while the extract from HS3-7 (yellow-orange pigment) lacked this carotenoid (Britton et al., 2004; Butnariu, 2016). In short, two species of Bacillus spp. (HS3-7 and HS8-3) producing the highest content of total carotenoid were selected for identification by using the 16sRNA sequencing method. 
Table 3. The highest absorbance and total carotenoid content of extract solutions from 20 isolates

\begin{tabular}{|c|c|c|c|c|}
\hline $\begin{array}{l}\text { Bacterial } \\
\text { strains }\end{array}$ & $\begin{array}{l}\text { The color of ex- } \\
\text { tracts }\end{array}$ & $\begin{array}{l}\text { Total carotenoid } \\
\text { content }(\mathrm{mg} / \mathrm{mL})\end{array}$ & $\begin{array}{r}\text { The highest absorb- } \\
\text { ance wavelength (nm) }\end{array}$ & $\begin{array}{l}\text { Predicted carotenoid } \\
\text { compounds }\end{array}$ \\
\hline HS1-1 & Pale yellow & $0.000741^{\mathrm{j}} \pm 0.025$ & 433 & \multirow{10}{*}{$\begin{array}{l}\alpha \text {-Carotene, } \\
\text { Zeaxanthin }\end{array}$} \\
\hline HS $1-3$ & Pale yellow & $0.000691^{\mathrm{k}} \pm 0.021$ & 433 & \\
\hline HS 1-4 & Pale yellow & $0.000536^{\circ} \pm 0.018$ & 433 & \\
\hline HS2-1 & Pale yellow & $0.000581^{\mathrm{n}} \pm 0.013$ & 434 & \\
\hline HS3-4 & Pale yellow & $0.000611^{\mathrm{m}} \pm 0.016$ & 434 & \\
\hline HS4-1 & Pale yellow & $0.000640^{1} \pm 0.010$ & 433 & \\
\hline HS6-1 & Pale yellow & $0.000476^{\mathrm{q}} \pm 0.012$ & 433 & \\
\hline HS8-6 & Pale yellow & $0.000504^{\mathrm{P}} \pm 0.012$ & 433 & \\
\hline HS8-7 & Pale yellow & $0.000405^{\mathrm{s}} \pm 0.016$ & 433 & \\
\hline HS8-8 & Pale yellow & $0.000439^{r} \pm 0.012$ & 434 & \\
\hline HS5-1 & Yellow & $0.00124^{\mathrm{f}} \pm 0.032$ & 448 & \multirow{4}{*}{$\gamma$-Carotene } \\
\hline HS5-3 & Yellow & $0.00130^{\mathrm{e}} \pm 0.015$ & 448 & \\
\hline HS7-1 & Yellow & $0.00155^{\mathrm{c}} \pm 0.016$ & 448 & \\
\hline HS8-9 & Yellow & $0.00137^{\mathrm{d}} \pm 0.010$ & 448 & \\
\hline HS3-7 & ellow-orange & $0.00287^{\mathrm{a}} \pm 0.018$ & 460 & $\begin{array}{l}\phi, \phi \text {-Carotene, } \\
\beta \text {-Carotene, } \\
\text { Zeaxanthin }\end{array}$ \\
\hline HS3-3 & Pale pink & $0.000823^{\mathrm{i}} \pm 0.016$ & 495 & \multirow{3}{*}{$\begin{array}{l}\text { Zeaxanthin, } \\
\phi, \phi \text {-Carotene }\end{array}$} \\
\hline HS3-8 & Pale pink & $0.000872^{\mathrm{h}} \pm 0.014$ & 495 & \\
\hline HS9-1 & Pale pink & $0.000912^{\mathrm{g}} \pm 0.018$ & 495 & \\
\hline 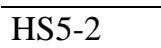 & Pink & $0.00157^{\mathrm{c}} \pm 0.018$ & 500 & \multirow{2}{*}{$\delta$-Carotene } \\
\hline HS8-3 & Pink & $0.00250^{\mathrm{b}} \pm 0.016$ & 500 & \\
\hline
\end{tabular}

*Values in the column with the same letters are not significantly different $(p<0.05)$ by Duncan post hoc test. Values were shown in the table as mean $\pm S D$ of triplicate.

\subsection{Identification of carotenoid producing strains}

The 16sRNA fragments of bacterial isolate (HS3-7 and HS8-3) were amplified by PCR and electrophoresed on $2 \%$ agarose gel for qualification. The results showed positive results, which indicated the presence of bacterial DNA with a base length of approximately $1500 \mathrm{bp}$ (Figure 2).

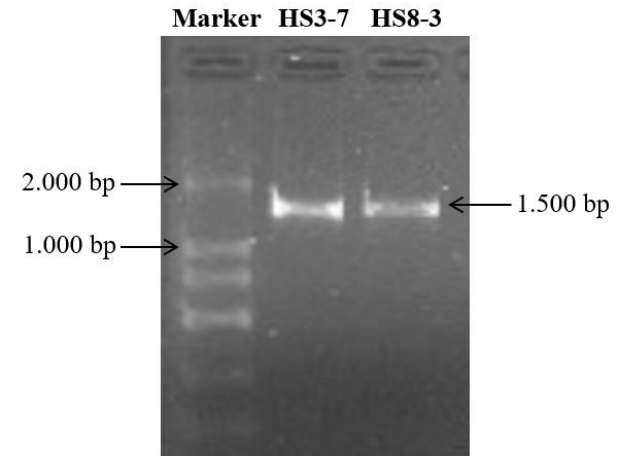

Figure 2. Electrophoresis of bands of HS3-7 and HS8-3
The 16S rRNA fragments of two isolates (HS3-7 and HS8-3) obtained from partial sequencing were $519 \mathrm{bp}$ and $532 \mathrm{bp}$, respectively (Figure 3 \& Figure $4)$. The obtained 16s rRNA sequences of two isolated strains were aligned to the bacterial 16s RNA sequences recorded in the gene database (NCBI) by using BLAST software. The results showed that the 16S rRNA gene sequence of HS3-7 had high similarity $(99.81 \%)$ with the gene sequence of Bacillus vietnamensis (strain Marseille-P799, accession no. LT558810), and the gene sequence of HS8-3 was $100 \%$ similarity with Bacillus infantis (strain NRRL B-14911, accession no. CP006643) (Table 4). From morphology, biochemical properties, and 16sRNA identification, it can be concluded that the bacterial strains, HS3-7 and HS8-3, were Bacillus vietnamensis and Bacillus infantis, respectively. 
TCAGGACGAACGCTGGCGGCGTGCCTAATACATGCAAGTCGAGCGGATTGATGGGAGCT TGCTCCCTGATATCAGCGGCGGACGGGTGAGTAACACGTGGGTAACCTGCCTGTAAGACT GGGATAACTCCGGGAAACCGGGGCTAATACCGGATAACTCATTTCCTCGCATGAGGAAAT GTTGAAAGGTGGCTTTTAGCTACCACTTACAGATGGACCCGCGGCGCATTAGCTAGTTGG TGAGGTAACGGCTCACCAAGGCGACGATGCGTAGCCGACCTGAGAGGGTGATCGGCCAC ACTGGGACTGAGACACGGCCCAGACTCCTACGGGAGGCAGCAGTAGGGAATCTTCCGCA ATGGACGAAAGTCTGACGGAGCAACGCCGCGTGAGTGATGAAGGTTTTCGGATCGTAAA GCTCTGTTGTTAGGGAAGAACAAGTGCCGTTCGAATAGGGCGGCACCTTGACGGTACCTA ACCAGAAAGCCACGGCTAACTACGTGCCAGCAGCCCGCGGTAA

Figure 3. The 16S rRNA gene sequence of HS3-7 bacterial strain GAGAGTTTGATCCTGGCTCAGGACGAACGCTGGCGGCGTGCCTAATACATGCAAGTCGAG CGGACGGATGGGAGCTTGCTCCCTGAAGTCAGCGGCGGACGGGTGAGTAACACGTGGGC AACCTGCCTGTAAGACTGGGATAACTTCGGGAAACCGGAGCTAATACCGGATAATGCAT AACCTCTCATGAGGCTATGCTGAAAGATGGTTTCGGCTATCACTTACAGATGGGCCCGCG GCGCATTAGCTAGTTGGTGAGGTAACGGCTCACCAAGGCAACGATGCGTAGCCGACCTG AGAGGGTGATCGGCCACACTGGGACTGAGACACGGCCCAGACTCCTACGGGAGGCAGCA GTAGGGAATCTTCCGCAATGGACGAAAGTCTGACGGAGCAACGCCGCGTGAGTGATGAA GGTTTTCGGATCGTAAAACTCTGTTGTCAGGGAAGAACAAGTGCCGGAGTAACTGCCGGC ACCTTGACGGTACCTGACCAGAAAGCCACGGCTAACTACGTGCCAGCAGCCGCGGTA

Figure 4. The 16S rRNA gene sequence of HS8-3 bacterial strain

Table 4. Comparison 16S rRNA of HS3-7 and HS8-3 with Gen bank on NCBI

\begin{tabular}{cllrr}
\hline No. & $\begin{array}{l}\text { Bacterial } \\
\text { strains }\end{array}$ & Species & $\begin{array}{r}\text { Query } \\
\text { Cover }\end{array}$ & $\begin{array}{r}\text { Percent } \\
\text { Identity Accession }\end{array}$ \\
\hline 1 & HS3-7 & Bacillus vietnamensis strain Marseille-P799 & $100 \%$ & $99.81 \%$ LT558810 \\
2 & HS8-3 & Bacillus infantis strain NRRL B-14911 & $100 \%$ & $100 \%$ CP006643 \\
\hline
\end{tabular}

Thirty-nine sequences obtained from aligning the sequences of strain HS3-7 and HS8-3 with the genebank were used for building the phylogenetic tree (Figure 5). The phylogram was constructed using the UPGMA method (Sneath and Sokal, 1973). The percentage of replicate trees in which the associated taxa clustered together in the bootstrap test (1000 replicates) are shown next to the branches (Felsenstein, 1985). The tree is drawn to scale, with branch lengths in the same units as those of the evolutionary distances used to infer the phylogenetic tree. The evolutionary distances were computed using the Maximum Composite Likelihood method (Tamura et al., 2004) and are in the units of the number of base substitutions per site. The differences in the composition bias among sequences were considered in evolutionary comparisons (Tamura \& Kumar, 2002). This analysis involved 41 nucleotide sequences. All positions containing gaps and missing data were eliminated (complete deletion option). There was a total of 447 positions in the final dataset. Evolutionary analyses were conducted in MEGA X (Kumar et al., 2018). The phylogram showed that the species HS7-3 and Bacillus vietnamensis were closely related and the bootstrap index of this branch (HS7-3) is 77\%, and the HS8-3 was also closely related to Bacillus infantis (bootstrap index of $100 \%$ ). 


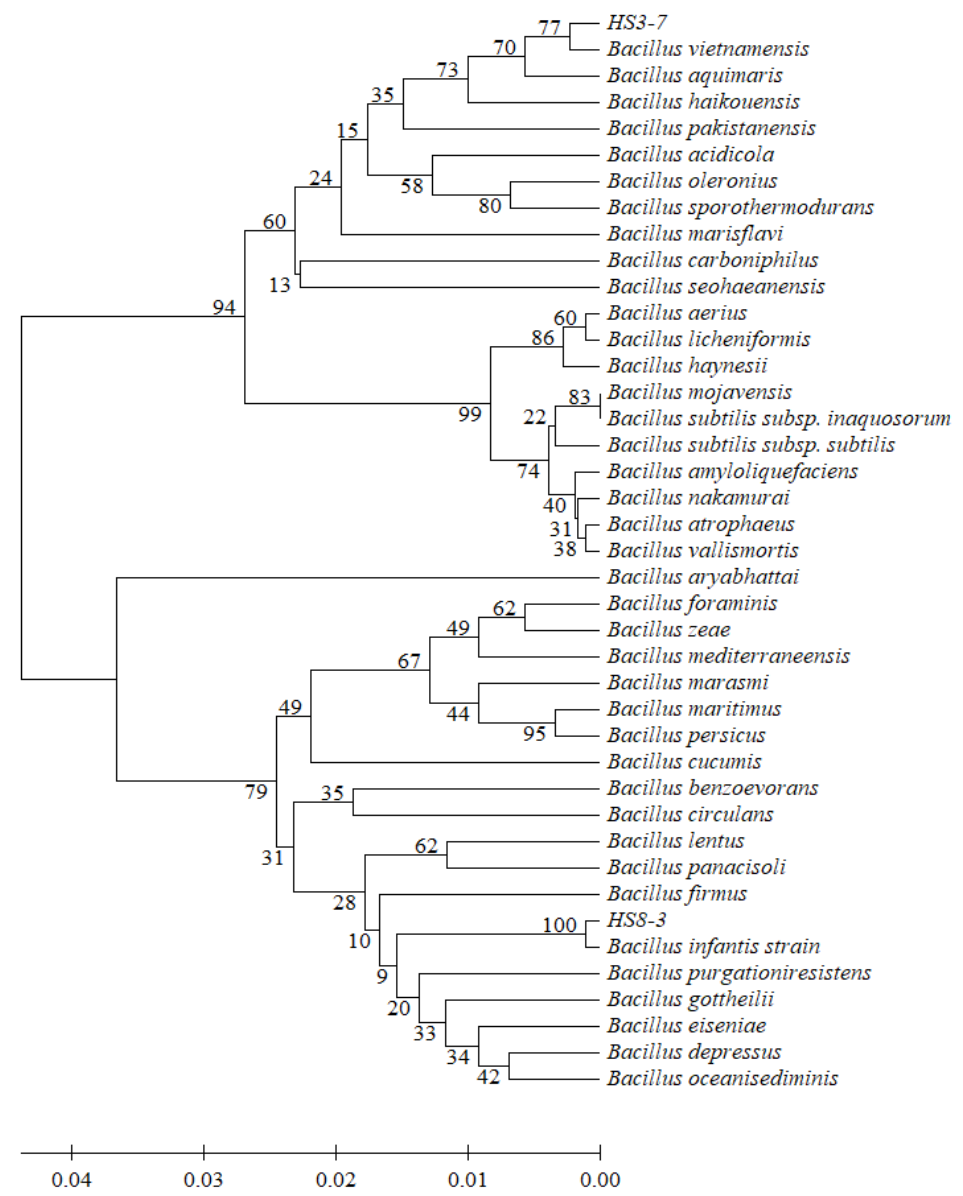

Figure 5. Phylogenetic tree generated by MEGA X of HS 3-7 and HS8-3 isolates

The scale bar indicates genetic distance and bootstrap percentages are represented on nodes.

\section{CONCLUSIONS}

Twenty pigment-producing bacterial species were discovered and isolated from seashore saline soils and seawater in Hon Son islet, Kien Hai district, Kien Giang province. There were five types of colony colors, namely pale yellow, yellow, yellow-orange, pale pink, and pink. All bacterial cells were rod-shaped, gram-positive, positive catalase test, motile, and able to form endospore, which is similar to the taxonomy characteristic of Bacillus spp. Carotenoids extracted from 20 isolates had the highest absorbance at wavelengths from 400 to $600 \mathrm{~nm}$. The total carotenoids extracted from HS3-7 strain (yellow-orange) and HS8-3 (pink) were the highest among 20 species. These two species were identified as Bacillus vietnamensis and Bacillus infantis based on morphology, biochemical properties, and 16sRNA partial sequencing data. It can be concluded that the marine bacteria isolated from $\mathrm{Vi}$ etnam coastal area can be used as the biological source for producing carotenoid natural pigments.

\section{REFERENCES}

Abdel-Fattah, A.M., Gamal-Eldeen, A.M., Helmy, W.A., \& Esawy, M.A. (2012). Antitumor and antioxidant activities of levan and its derivative from the isolate Bacillus subtilis NRC1aza. Carbohydrate polymers, 89(2), 314-322. https://doi.org/10.1016/j.carbpol.2012.02.041.

Abdulkadir, M., \& Waliyu, S. (2012). Screening and isolation of the soil bacteria for ability to produce antibiotics. European Journal of Applied Sciences, 4(5), 211-215. https://doi.org 10.5829/idosi.ejas.2012.4.5.2011

Amin, A., Khan, M.A., Ehsanullah, M., Haroon, U., Azam, S.M.F., \& Hameed, A. (2012). Production of peptide antibiotics by Bacillus sp: GU 057 indigenously isolated from saline soil. Brazilian Journal of 
Microbiology, 43(4): 1340-1346.

http://doi.org/10.1590/S1517-83822012000400015

Asker, D., Awad, T. S., Beppu, T., \& Ueda, K. (2012). Isolation, characterization, and diversity of novel radio tolerant carotenoid-producing bacteria. In J. L. Barredo (Ed.). Microbial Carotenoids from Bacteria and Microalgae (Methods and Protocols) (pp.2160). Humana Press, Totowa, NJ. https://doi.org/10.1007/978-1-61779-879-5_3

Britton, G., Liaaen-Jensen, S., \& Pfander, H. (2004). Section II: Main List Natural carotenoids. In G. Britton \& H. Pfander (Eds.). Carotenoids: Handbook, First Edition (pp.29-296). Birkhäuser Basel. Basel.

Butnariu, M. (2016). Methods of analysis (extraction, separation, identification, and quantification) of carotenoids from natural products. Journal of Ecosystem \& Ecography, 6(2): 1-19. https://doi.org/10.4172/2157-7625.1000193

Duc, L. H., Fraser, P. D., Tam, N. K., \& Cutting, S. M. (2006). Carotenoids present in halotolerant Bacillus spore formers. FEMS microbiology letters, 255(2), 215-224. https://doi.org/10.1111/j.15746968.2005.00091.x

Felsenstein, J. (1985). Confidence limits on phylogenies: an approach using the bootstrap. evolution, 39(4),783-791. https://doi.org/10.1111/j.15585646.1985.tb00420.x

Fiedor, J., \& Burda, K. (2014). Potential role of carotenoids as antioxidants in human health and disease. Nutrients, 6(2), 466-488. https://doi.org/10.3390/nu6020466.

Holt, J. G., Kreig, P. H. A., \& Sneath, J. T. S. (1994). Bergey's Manual of Determinative Bacteriology $\left(9^{\text {th }}\right.$ ed.). Williams and Wilkins, Baltimore.

Indra Arulselvi, P., Umamaheswari, S., Ranandkumar, S. G., Karthik, C., \& Jayakrishna, C. (2014). Screening of yellow pigment producing bacterial isolates from various eco-climatic areas and analysis of the carotenoid produced by the isolate. Journal of Food Processing \& Technology, 5(1). https://doi.org/10.4172/2157-7110.1000292

Khaneja, R., Perez-Fons, L., Fakhry, S., Baccigalupi, L., Steiger, S., To, E., Sandmann, G., Dong, T.C., Ricca, E., \& Cutting, S. M. (2010). Carotenoids found in Bacillus. Journal of applied microbiology, 108(6), 1889-1902.

https://doi.org/10.1111/j.1365-2672.2009.04590.x

Kumar, S., Stecher, G., Li, M., Knyaz, C., \& Tamura, K. (2018). MEGA X: molecular evolutionary genetics analysis across computing platforms. Molecular biology and evolution, 35(6), 1547-1549. https://doi.org/10.1093/molbev/msy096

Liaaen-Jensen, S., \& Jensen, A. (1971). Quantitative determination of carotenoids in photosynthetic tissues. In Methods in enzymology (Vol. 23, pp. 586-602). Academic Press. https://doi.org/10.1016/S00766879(71)23132-3
Mitchell, C., Iyer, S., Skomurski, J. F., \& Vary, J. C. (1986). Red pigment in Bacillus megaterium spores. Applied and environmental microbiology, 52(1), 64-67.

Nicholson, W. L., Munakata, N., Horneck, G., Melosh, H. J., \& Setlow, P. (2000). Resistance of Bacillus endospores to extreme terrestrial and extraterrestrial environments. Microbiology and molecular biology reviews, 64(3), 548-572. https://doi.org/10.1128/MMBR.64.3.548-572.2000

Nielsen, P., Fritze, D., \& Priest, F. G. (1995). Phenetic diversity of alkaliphilic Bacillus strains: proposal for nine new species. Microbiology, 141(7), 1745-1761. https://doi.org/10.1099/13500872-141-7-1745

Nugraheni, S. A., Khoeri, M. M., Kusmita, L., Widyastuti, Y., \& Radjasa, O. K. (2010). Characterization of carotenoid pigments from bacterial symbionts of seagrass Thalassia hemprichii. Journal of Coastal Development, 14(1), 51-60.

Oktari, A., Supriatin, Y., Kamal, M., \& Syafrullah, H. (2017). The bacterial endospore stain on schaeffer fulton using variation of methylene blue solution. Journal of Physics: Conference Series (Vol. 812, No. 1, p. 012066). IOP Publishing.

Dang, H., \& Lovell, C. R. (2000). Bacterial primary colonization and early succession on surfaces in marine waters as determined by amplified rRNA gene restriction analysis and sequence analysis of $16 \mathrm{~S}$ rRNA genes. Applied and environmental microbiology, 66(2), 467-475. https://doi.org/10.1128/AEM.66.2.467-475.2000

Andrews, P. H., \& Sokal, R. R. (1973). Numerical taxonomy: The principles and practice of numerical classification. WH Freeman.

Tamura K., Nei M., and Kumar S. (2004). Prospects for inferring very large phylogenies by using the neighbor-joining method. Proceedings of the National Academy of Sciences (USA), 101, 11030-11035. https://doi.org/doi:10.1073/pnas.0404206101

Tamura, K., \& Kumar, S. (2002). Evolutionary distance estimation under heterogeneous substitution pattern among lineages. Molecular biology and evolution, 19(10), 1727-1736. https://doi.org/10.1093/oxfordjournals.molbev.a003995

Tittsler, R. P., \& Sandholzer, L. A. (1936). The use of semi-solid agar for the detection of bacterial motility. Journal of bacteriology, 31(6), 575.

Vílchez, C., Forján, E., Cuaresma, M., Bédmar, F., Garbayo, I., \& Vega, J. M. (2011). Marine carotenoids: biological functions and commercial applications. Marine Drugs, 9(3), 319-333. https://doi.org/10.3390/md9030319

Yoon, J. H., Kim, I. G., Kang, K. H., Oh, T. K., \& Park, Y. H. (2003). Bacillus marisflavi sp. nov. and Bacillus aquimaris sp. nov., isolated from sea water of a tidal flat of the Yellow Sea in Korea. Journal of Medical Microbiology, 53(5), 1297-1303. https://doi.org/10.1099/ijs.0.02365-0. 